\title{
Responses of explant type of wheat (Triticum aestivum L.) genotypes to different tissue culture media
}

\author{
Imran Mahmood* and Abdul Razzaq \\ Department of Agronomy, Faculty of Crop and Food Sciences, Pir Mehr Ali Shah, Arid Agriculture University, Rawalpindi-46300, Pakistan.
}

\begin{abstract}
Wheat recalcitrance to in vitro culture is one of the most important and crucial steps for its genetic transformation, and is directly associated with the ability of the explant to regenerate, composition of the media and genotype. Callus induction and regeneration potential of various explants, viz, mature embryo, immature embryo, endosperm supported (ES) mature embryo and shoot apical meristem, taken from the same plants of two wheat genotypes (AS-2002 and GA-2002) were investigated using Murashige and Skoog (MS) basal callus induction medium supplemented with $2,4,6$ or $8 \mathrm{mg} / \mathrm{L}$ of 2,4-dichlorophenoxyacetic acid (2,4-D) and regeneration media comprising various combinations of auxins and cytokinins. In vitro culture response of the explants taken from the same plant varied from each other and was influenced by the genotype and media composition. Immature embryo culture of genotype AS-2002 exhibited the highest callusing ability (84.75\%) followed by the mature embryo culture of genotype GA-2002 (78.50\%). Similarly, immature embryos cultured on MS basal medium supplemented with $4 \mathrm{mg} / \mathrm{L} 2,4-\mathrm{D}$ and mature embryos cultured on MS basal medium supplemented with $6 \mathrm{mg} / \mathrm{L} 2,4-\mathrm{D}$ exhibited the highest callusing ability of 90.83 and $88.33 \%$, respectively. Immature embryos of genotype GA-2002 cultured on MS based regeneration medium supplemented with $0.2 \mathrm{mg} / \mathrm{L}$ 2,4-D, $0.5 \mathrm{mg} / \mathrm{L}$ zeatin and $0.5 \mathrm{mg} / \mathrm{L}$ benzylaminopurine (BAP) showed a significantly higher regenerating potential. ES mature embryos of genotypes GA-2002 and AS-2002 cultured on regeneration medium comprising $0.4 \mathrm{mg} / \mathrm{L} 2,4-\mathrm{D}, 1.0 \mathrm{mg} / \mathrm{L}$ zeatin and $1.5 \mathrm{mg} / \mathrm{L}$ BAP showed maximum regeneration potentials of 59.67 and $59.0 \%$, respectively. Appraisal of the responses of the four explants used showed that endospermsupported mature embryo is the most suitable explant for plant regeneration in wheat.
\end{abstract}

Keywords: Auxins, cytokinins, in vitro, regeneration, somatic embryogenesis, totipotency.

\section{INTRODUCTION}

The world population is projected to grow from 6 to 8 billion by 2020 (Wagiran et al., 2010). Efforts are being made to address the increasing food demand of the world population by breeding genotypes with increased yield potential and resistance/tolerance to a wide range of biotic and abiotic stresses through genetic transformation, coupled with conventional breeding approaches. Up till now, genetic modification of wheat was carried out through gene gun and agrobacterium-mediated transformation involving callus phase (Razzaq et al., 2011), where the major bottleneck is not the delivery of the genes but the establishment of long-term cultures and finally the regeneration of transformed plants.

Wheat (Triticum aestivum L.) is amongst the most recalcitrant cereals to in vitro culture (Razzaq et al., 2011), since its embryogenic callus formation and regeneration of transformed plants, besides genotypic and media composition (Chen et al., 2006; Mahmood et al., 2012c; Gill et al., 2014), are explant dependent (Sarker \& Biswas, 2002; Chen et al., 2006; Gill et al., 2014). In cereal tissue culture, not all cells express totipotency (Shah et al., 2003) and the choice of a favourable explant and genotype is required for the success in tissue culture approaches. Therefore, the success of any callus-based transformation strategy depends largely upon the regeneration capability of the target explant and the genotype (Chugh \& Khurana, 2003), and efforts are being made to increase their callusing and regeneration efficiencies by using various combinations of phytohormones (Mahmood et al., 2012c).

*Corresponding author (imran_agri@yahoo.com) 
Generally, immature embryo is preferred as an explant source for tissue culture and genetic transformation studies of wheat due to its superb callusing and regeneration potential (Sarker \& Biswas, 2002; Vendruscolo et al., 2008; Aguado-Santacruz et al., 2011; Mahmood et al., 2012a, 2012b, 2012c; Gill et al., 2014; Yang et al., 2015). However, the production of immature embryos throughout the year is a space, time and labour intensive task and appears to be not feasible. In addition, the lack of competence of immature embryos in certain elite lines is still a barrier to routine production of transgenic commercial genotypes. Therefore, alternative explants and regeneration systems are needed for efficient transformation of cereal crops to avoid or reduce the above limitations.

The selection of a promising explant, genotype and the development of a reliable regeneration system with an intervening callus phase would certainly augment the genetic transformation of wheat (Mahmood et al., 2012c). Explants such as the shoot apex (AguadoSantacruz et al., 2011), mature seed (Shah et al., 2003), isolated mature embryos (Vendruscolo et al., 2008; Gill et al., 2014), endosperm supported (ES) mature embryo (Birsin \& Ozgen, 2004; Aydin et al., 2011) and coleoptiles (Benkirane et al., 2000) are deployed to study tissue culture responses of wheat, and are found more convenient and easily available throughout the year. However, comparative studies regarding callusing and regeneration potential of these explants taken from the same plants of various genotypes in response to various combinations of growth regulators are limited.

The present study is an attempt to test the hypothesis that tissue culture responses of wheat explants taken from the same plant differ from each other and is dependent on the genotype and media composition. In addition, callusing and regeneration potential of various explants (mature embryo, immature embryo, ES mature embryo and shoot epical meristem) of wheat genotypes was explored, and a reliable callus induction and regeneration protocol for each explant was established with the future aim of exploitation of somaclonal variation, and biolistic and agrobacterium-mediated genetic transformation for breeding biotic and abiotic stress tolerant plants of wheat.

\section{METHODOLOGY}

\section{Plant material}

Preliminary studies conducted have shown that wheat genotypes GA-2002 and AS-2002 have the highest tissue culture responses among seven genotypes tested (Mahmood et al., 2012c). Therefore, genotypes GA-2002 and AS-2002 were selected for the present study. Tissue culture responses of various explants, viz, immature embryo, mature embryo, ES mature embryo and shoot apical meristem, taken from the same plants of wheat genotypes AS-2002 and GA-2002 were tested, and the callus induction and regeneration media were standardised for each explant.

\section{Sterilisation}

The explants were surface sterilised aseptically with $90 \%$ ethanol for 5 min followed by rinsing with 3 changes of sterile distilled water. The explants were again sterilised with a $6.5 \%$ solution of sodium hypochlorite containing $0.1 \%$ Tween-20 for 30 min. Finally, the explants were thoroughly washed with 4 changes of sterile distilled water.

\section{Explants preparation for callus induction}

The seeds of both genotypes were sown in earthenware pots and explants were collected as explained below.

\section{Immature embryo}

The seeds of genotypes were raised in pots and immature caryopses at the milk ripe to soft dough stages (about $15-18$ ds post-anthesis) were collected from the middle portion of the spikes. The spikes were not detached from the plants. Immature embryos were aseptically excised from caryopses and placed on induction medium with the scutellum facing up. The remaining spikes/caryopses of the plants from which immature embryos were collected, were raised to maturity and the seeds were collected for mature embryo, ES mature embryo and shoot epical meristem explants.

\section{Mature embryo}

The mature caryopses were surface sterilised and immersed overnight in sterile distilled water. The embryos were excised and placed on induction medium facing the scutellum side up.

\section{Endosperm supported mature embryo}

After surface sterilisation, the mature seeds were immersed in sterile distilled water for $4 \mathrm{~h}$ at $30^{\circ} \mathrm{C}$. Mature embryos of the immersed seeds were aseptically removed slightly (not set free from endosperm) with a scalpel. The seeds with removed embryos were placed furrow downwards in sterile Petri dishes containing induction medium. 


\section{Shoot apical meristem}

The sterilised seeds were soaked for germination. Before emergence of coleoptiles apical meristems $(3 \mathrm{~mm}$ sections of shoot apices) were dissected. Vertical cross slits were made at the base of each dissected apex to enhance callus induction. The explants were placed horizontally on induction medium and incubated.

\section{Callus induction}

MS basal media (Murashige \& Skoog, 1962) supplemented with $30 \mathrm{~g} / \mathrm{L}$ sucrose, $6 \mathrm{~g} / \mathrm{L}$ agar and various concentrations of 2,4-D (2, 4, 6 or $8 \mathrm{mg} / \mathrm{L})$ were used to induce callus from various explants of wheat. Prior to autoclaving at $121{ }^{\circ} \mathrm{C}$ for $20 \mathrm{~min}, \mathrm{pH}$ of the medium was adjusted to 5.8. The explants were incubated in total darkness at $25 \pm 1{ }^{\circ} \mathrm{C}$ for $21 \mathrm{ds}$, replacing the media after each week. The callus induction potential of explants of both genotypes were calculated on percentage basis.

\section{Regeneration}

The regeneration potential of the explants (immature embryo, mature embryo, ES mature embryo and shoot apical meristem) with an intervening callus phase was evaluated in this step. Fresh calli were induced from each explant using their respective best suited callus induction medium (MS basal medium $+30 \mathrm{~g} / \mathrm{L}$ sucrose $+6 \mathrm{~g} / \mathrm{L}$ agar and best suited concentration of 2,4-D for callus induction for the respective explants of each genotype), as determined in the previous step of this study. The calli were cultured on fresh maintenance medium (half of the best suited concentration of 2, 4-D for callus induction of the respective genotype) for a further period of $3 \mathrm{wks}$, replacing the callus maintenance medium after every $14-21$ days. Morphogenic calli (nodular and solid calli with white to pale yellow surface) showing high potential were then shifted on to regeneration media (MS basal medium $+30 \mathrm{~g} / \mathrm{L}$ sucrose $+6 \mathrm{~g} / \mathrm{L}$ agar + various combinations of phytohormones). The calli were incubated at $26^{\circ} \mathrm{C}$ with $16 \mathrm{~h}$ light and $8 \mathrm{~h}$ dark photoperiod. After $25-30 \mathrm{ds}$, calli with clearly differentiated shoots were scored as regenerating calli. Each piece of regenerating callus was counted as one regardless of the number of shoots and roots. The various regeneration protocols tested are given in Table 1.

\section{Experimental design}

The experiment was laid out following a completely randomised design (CRD) with factorial arrangements, and replicated thrice. The data collected were analysed using analysis of variance (ANOVA) and least significant difference (LSD) $(\alpha=0.05)$ using Statistics 8.1.1.0 software.

Table 1: Treatments/regeneration protocols tested in the study (combinations of various concentrations of phytohormones)

\begin{tabular}{lccc}
\hline Media & $\begin{array}{c}2,4-\mathrm{D} \\
(\mathrm{mg} / \mathrm{L})\end{array}$ & $\begin{array}{c}\text { Zeatin } \\
(\mathrm{mg} / \mathrm{L})\end{array}$ & $\begin{array}{c}\text { BAP } \\
(\mathrm{mg} / \mathrm{L})\end{array}$ \\
\hline $\mathrm{M}_{1}$ & 0.0 & 1.0 & 0.0 \\
$\mathrm{M}_{2}$ & 0.2 & 0.5 & 0.5 \\
$\mathrm{M}_{3}$ & 0.4 & 1.0 & 1.0 \\
$\mathrm{M}_{4}$ & 0.6 & 1.5 & 1.5 \\
\hline
\end{tabular}

\section{RESULTS AND DISCUSSION}

The callusing and regeneration potential of various explants (mature embryo, immature embryo, ES mature embryo and shoot epical meristem) of the two wheat genotypes, viz, GA-2002 and AS-2002 were investigated by using various callus induction and regeneration protocols. The callogenesis response of various explants of cv. GA-2002 and AS-2002 varied significantly between 24.92 to $84.75 \%$ (Table 2). The callogenesis response of both immature and mature embryos were significantly the highest compared to the rest of the explants with mean callus induction percentages of 80.21 and $79.86 \%$, respectively (Table 2). However, in vitro culture response of the explants was influenced by the genotypes and media composition. Immature embryo culture of genotype AS-2002 exhibited the highest callusing ability (84.75\%) followed by the mature embryo culture of genotype GA-2002 (78.50\%). Similarly, the immature embryo cultured on MS basal medium supplemented with $4 \mathrm{mg} / \mathrm{L} \mathrm{2,4-D}$ and the mature embryo cultured on MS basal medium supplemented with

Table 2: Callogenesis response of various explants of genotype GA-2002 and AS-2002

\begin{tabular}{llll}
\hline & \multicolumn{3}{c}{ Callogenesis percentage (\%) } \\
Explants & GA-2002 & AS-2002 & Mean \\
\hline \multirow{2}{*}{ Immature embryo } & $75.67^{\mathrm{CD}}$ & $84.75^{\mathrm{A}}$ & $80.21^{\mathrm{A}}$ \\
Mature embryo & $78.50^{\mathrm{BC}}$ & $81.25^{\mathrm{B}}$ & $79.86^{\mathrm{A}}$ \\
ES mature embryo & $69.17^{\mathrm{E}}$ & $73.33^{\mathrm{D}}$ & $71.25^{\mathrm{B}}$ \\
Shoot epical meristem & $24.92^{\mathrm{G}}$ & $30.17^{\mathrm{F}}$ & $27.54^{\mathrm{C}}$ \\
Mean & $62.06^{\mathrm{B}}$ & $67.38^{\mathrm{A}}$ & \\
\hline
\end{tabular}

LSD: genotype $=1.621 ;$ explants $=2.292 ;$ genotype $\times$ explants $=3.242$ Entries sharing common letters do not differ significantly $(\alpha=0.05)$ 
$6 \mathrm{mg} / \mathrm{L}$ 2,4-D exhibited the highest callusing abilities of 90.83 and $88.33 \%$, respectively. On the contrary, the least callus frequency $(10.83 \%)$ was observed for shoot epical meristems with $2 \mathrm{mg} / \mathrm{L}$ of 2,4-D (Table 3 ).
In general, genotype AS-2002 exhibited a significantly higher callus induction percentage than cv. GA-2002 with respective callus induction percentages of 67.38 and $62.06 \%$ (Table 2).

Table 3: Callogenesis response of explants of wheat genotypes to various concentrations of auxins (2,4-D)

\begin{tabular}{lcccc}
\hline & \multicolumn{4}{c}{ Callogenesis percentage (\%) } \\
Explants & $2 \mathrm{mg} / \mathrm{L}$ & $4 \mathrm{mg} / \mathrm{L}$ & $6 \mathrm{mg} / \mathrm{L}$ & $8 \mathrm{mg} / \mathrm{L}$ \\
\hline \multirow{2}{*}{ Immature embryo } & $78.33^{\mathrm{DE}}$ & $90.83^{\mathrm{A}}$ & $84.33^{\mathrm{BC}}$ & $67.33^{\mathrm{G}}$ \\
Mature embryo & $73.33^{\mathrm{F}}$ & $83.83^{\mathrm{BC}}$ & $88.33^{\mathrm{AB}}$ & $74.00^{\mathrm{EF}}$ \\
ES mature embryo & $55.83^{\mathrm{H}}$ & $72.83^{\mathrm{F}}$ & $80.33^{\mathrm{CD}}$ & $76.00^{\mathrm{DEF}}$ \\
Shoot epical meristem & $10.83^{\mathrm{K}}$ & $27.83^{\mathrm{J}}$ & $35.50^{\mathrm{I}}$ & $36.00^{\mathrm{I}}$ \\
Mean & $54.58^{\mathrm{D}}$ & $68.83^{\mathrm{B}}$ & $72.12^{\mathrm{A}}$ & $63.33^{\mathrm{C}}$ \\
\hline
\end{tabular}

LSD: explants $\times 2,4-\mathrm{D}=4.585$

Entries sharing common letters do not differ significantly $(\alpha=0.05)$

Non-significant differences were recorded in the regeneration potential of immature embryo and ES mature embryo culture with respective mean regeneration potentials of 45.54 and $46.33 \%$ (Table 4). However, the regeneration potential of the explants was genotype and media specific (Figure 1). Immature embryo of the genotype GA-2002 cultured on MS based regeneration medium supplemented with $0.2 \mathrm{mg} / \mathrm{L} 2,4-\mathrm{D}, 0.5 \mathrm{mg} / \mathrm{L}$ zeatin and $0.5 \mathrm{mg} / \mathrm{L}$ benzylaminopurine (BAP) showed significantly the highest regenerating potential $(60.0 \%)$. ES mature embryos of genotypes GA-2002 and AS-2002 cultured on regeneration medium comprising $0.4 \mathrm{mg} / \mathrm{L}$ 2,4-D, $1.0 \mathrm{mg} / \mathrm{L}$ zeatin and $1.0 \mathrm{mg} / \mathrm{L}$ BAP showed the maximum regeneration potentials of 59.67 and $59.0 \%$,
Table 4: Regeneration response of various explants of genotype GA-2002 and AS-2002

\begin{tabular}{llll}
\hline & \multicolumn{3}{c}{ Regeneration response (\%) } \\
Explant & GA-2002 & AS-2002 & Mean \\
\hline \multirow{2}{*}{ Immature embryo } & $48.33^{\mathrm{A}}$ & $42.75^{\mathrm{C}}$ & $45.54^{\mathrm{A}}$ \\
Mature embryo & $42.17^{\mathrm{CD}}$ & $40.25^{\mathrm{D}}$ & $41.21^{\mathrm{B}}$ \\
ES mature embryo & $45.42^{\mathrm{B}}$ & $47.25^{\mathrm{AB}}$ & $46.33^{\mathrm{A}}$ \\
Shoot epical meristem & $27.75^{\mathrm{E}}$ & $28.42^{\mathrm{E}}$ & $28.08^{\mathrm{C}}$ \\
Mean & $40.92^{\mathrm{A}}$ & $39.67^{\mathrm{B}}$ & \\
\hline
\end{tabular}

LSD: genotype $\times$ explants $=2.140$

Entries sharing common letters do not differ significantly $(\alpha=0.05)$

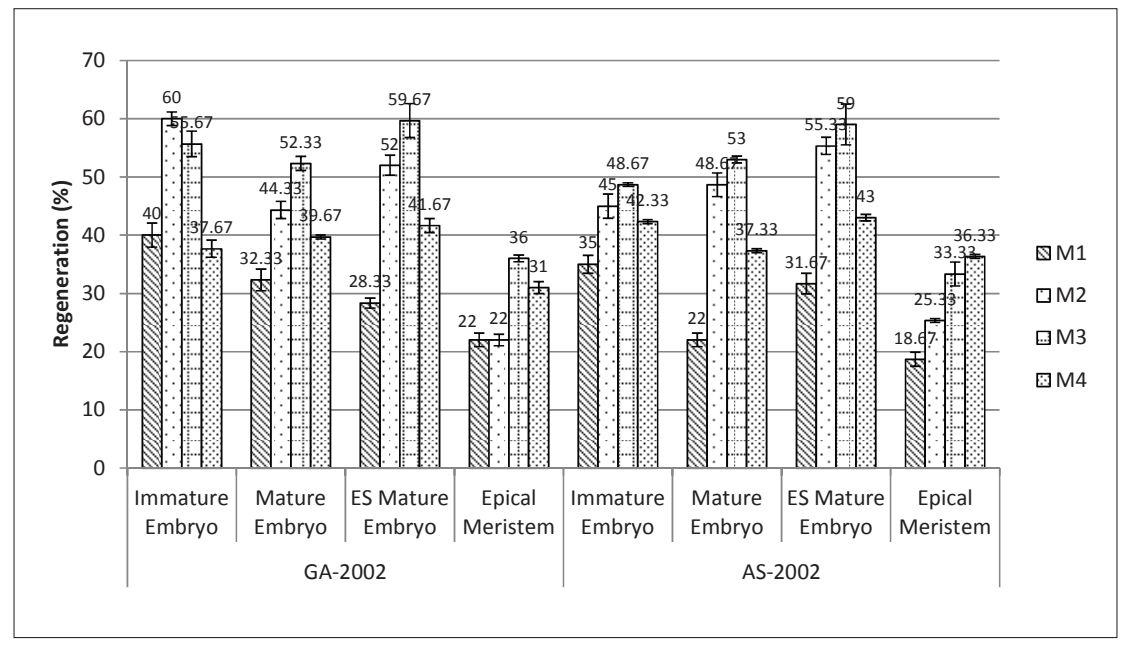

Figure 1: Regeneration response of various explants of genotype GA-2002 and AS-2006 to various regeneration media 
respectively. The least regeneration potential (18.67\%) was observed for shoot epical meristems of genotype AS-2002 (Figure 1).

Genotype GA-2002 exhibited a significantly higher regeneration potential (mean $40.92 \%$ ) than genotype AS-2002 (mean $39.67 \%$; Table 4). In general, regeneration medium $\mathrm{M}_{3}(0.4 \mathrm{mg} / \mathrm{L}$ of $2,4-\mathrm{D}, 1.0 \mathrm{mg} / \mathrm{L}$ zeatin and $1.0 \mathrm{mg} / \mathrm{L} \mathrm{BAP}$ ) was found to be superior for regeneration of both wheat genotypes followed by $\mathrm{M}_{2}$ $(0.2 \mathrm{mg} / \mathrm{L}$ of $2,4-\mathrm{D}, 0.5 \mathrm{mg} / \mathrm{L}$ zeatin and $0.5 \mathrm{mg} / \mathrm{L} \mathrm{BAP})$, with mean regeneration responses of 49.71 and $44.08 \%$, respectively (Table 5).

Table 5: Regeneration response of wheat genotypes to various regeneration media

\begin{tabular}{|c|c|c|c|}
\hline \multirow[b]{2}{*}{$\begin{array}{l}\text { Regeneration } \\
\text { media }\end{array}$} & \multicolumn{3}{|c|}{ Regeneration response (\%) } \\
\hline & GA-2002 & AS-2002 & Mean \\
\hline $\mathrm{M}_{1}$ & $30.67^{\mathrm{F}}$ & $26.83^{\mathrm{G}}$ & $28.75^{\mathrm{D}}$ \\
\hline $\mathrm{M}_{2}$ & $44.58^{\mathrm{C}}$ & $43.58^{\mathrm{C}}$ & $44.08^{\text {в }}$ \\
\hline $\mathrm{M}_{3}$ & $48.50^{\mathrm{B}}$ & $50.92^{\mathrm{A}}$ & $49.71^{\mathrm{A}}$ \\
\hline $\mathrm{M}_{4}$ & $37.50^{\mathrm{E}}$ & $39.75^{\mathrm{D}}$ & $38.62^{\mathrm{C}}$ \\
\hline
\end{tabular}

LSD values: genotype $\times$ regeneration media $=2.140$

Entries sharing common letters do not differ significantly $(\alpha=0.05)$

In contrast to other monocotyledons, not all wheat genotypes are responsive to tissue culture procedures due to lack of secondary growth through cambium tissues (Shah et al., 2009). The regeneration ability of explants is under the influence of at least two complementary dominant genes; or different genes or combinations of genes may govern the different stages from callus induction to plantlet regeneration (Jia et al., 2009). Therefore, genotypes and explants vary in their ability to regenerate whole plants. Also, varying tissue culture responses of the explants and genotypes are associated with the cytoplasmic composition of the cells (Ma et al., 1987). In addition, variable tissue culture responses of wheat genotypes are mainly due to the genotypic and media interaction. Conditions conducive for tissue culture responses of one genotype are usually not conducive for another genotype of the same species (Mahmood et al., 2012c). Due to this reason genotype AS-2002 and GA2002 varied for tissue culture responses. Some reports have suggested that there are no notable variations in the callus induction and regeneration potential of various genotypes of wheat (Sarker \& Biswas, 2002).
Auxins play a vital role in gene activation involved in cell division and dedifferentiation (Dudits et al., 1991). Also, cell division, callus proliferation, regeneration and recovery of transformed plants are mainly determined by the type and concentration of auxins (Barro et al., 1999). Various phytohormones including indole-3-acetic acid (IAA), BAP and kinetin (Kn) are being used alone or in combinations for the regeneration of various explants with an intervening callus phase (Noor et al., 2009; Mahmood et al., 2012c). However, the interactions of phytohormones like auxins and cytokinins are complex and more than one combination of two substances or changes in their relative proportion is likely to produce optimum results (Mahmood et al., 2012c), and they influence rate and growth patterns of the explants. Similarly, auxins are critical for callus induction and have a negative role in explant regeneration, and are therefore reduced or excluded from regeneration medium. Hence, the developed callus can be enforced to form shoots by decreasing the auxin or increasing the cytokinin concentrations in culture media (Mahmood et al., 2012c).

Unlike callogenesis from immature embryos at lower concentrations of auxins, a relatively higher concentration of auxins (2,4-D) was required to induce calli from mature embryos, ES mature embryos and epical meristem (Table 3), and this fact is supported by Fazeli-Nasab et al. (2012) and Gill et al. (2014). Mature embryos contain more old cells and more differentiated tissues than immature embryos, which necessitate the use of a high concentration of auxins for dedifferentiation. In the case of ES mature embryo culture, the endosperm can absorb some proportion of the added plant growth regulators, which requires a higher concentration of auxins (Aydin et al., 2011). Profuse callus induction from immature embryo and ES mature embryo is reported by the use of $2 \mathrm{mg} / \mathrm{L}$ and $8 \mathrm{mg} / \mathrm{L}$ of 2,4-D, respectively (Özgen et al., 1998). Generally, $5.5-6.0 \mathrm{mg} / \mathrm{L}$ of 2,4-D is considered optimum for callogenesis of various explants including immature embryos, mature embryos, seeds, endosperm, root tips and shoot bases (Sarker \& Biswas, 2002).

An optimum concentration of auxins and cytokinins results in maximum regeneration of explants (Mahmood et al., 2012c). For example, regeneration medium supplemented with $0.2 \mathrm{mg} / \mathrm{L}$ IAA, $0.5 \mathrm{mg} / \mathrm{L} \mathrm{Kn}$ and $0.5 \mathrm{mg} / \mathrm{L}$ of BAP was proved excellent for obtaining maximum regeneration of callus induced from immature embryos (Mahmood et al., 2012c). Similarly, for shoot regeneration from immature embryonic calli of wheat 
$0.5 \mathrm{mg} / \mathrm{L}$ BAP, $0.5 \mathrm{mg} / \mathrm{L} \mathrm{Kn}$ and $25 \mathrm{mg} / \mathrm{L}$ tyrosine have shown the best response. On the contrary, $0.5 \mathrm{mg} / \mathrm{L}$ BAP, $0.5 \mathrm{mg} / \mathrm{L}$ IAA and $40 \mathrm{mg} / \mathrm{L}$ tyrosine have been reported best for shoot regeneration of mature embryonic calli of wheat (Sarker \& Biswas, 2002).

In cereal tissue culture, embryogenic callus formation and regeneration potential besides genotype and media composition (Mahmood et al., 2012c), are also dependent on the explant source because not all cells are totipotenic (Shah et al., 2003). Various explants taken even from the same plant of a genotype differ in their regeneration potential (Sarker \& Biswas, 2002). Therefore, the choice of a favourable explant is inevitable for the success of tissue culture based transformation of cereals. Most of the studies and reviews have shown that immature embryos are the best explants in terms of regeneration (Yang et al., 2015). The results reported in the present study also indicated that explants of both genotypes have different callusing abilities (Table 2), and that the callogenesis response of explants is genotype and media dependent (Table 3). Yang et al. (2015) have also reported significant interaction effects between genotypes and explant types, and revealed that different explants of various wheat lines have different callusing potentials. However, calli derived from immature embryos had higher differentiation and regeneration potentials than those from mature embryos (Yang et al., 2015). Similarly in wheat, the callus induction percentage of mature embryos is significantly higher than ES mature embryos cultured in the absence of endosperm (non-endosperm supported culture), regardless of the 2,4-D concentration ( 2 or $8 \mathrm{mg} / \mathrm{L}$ 2,4-D) used in induction medium (Chen et al., 2006). However, endosperm supported calli had a higher regeneration potential than the non-endosperm supported ones mainly because of higher oxalate oxidase activity (Chen et al., 2006).

The results presented here depicted that immature embryo and ES mature embryo had no significant differences in regeneration potential under the tested conditions (Figure 1), and ES mature embryo can be a valuable explant for genetic transformation of wheat.

\section{CONCLUSION}

In vitro culture response of explants taken from the same plant of wheat genotypes differs from each other, and is influenced by the genotype and media composition. Immature and mature embryos had the highest callusing ability ( 80.21 and $79.86 \%$, respectively) than the rest of the explants. However, ES mature embryo explants and immature embryo explants had non significant differences in regeneration potential, with regeneration potentials of 46.33 and $45.54 \%$, respectively, showing that ES mature embryo explants are an alternative to immature embryo explants of wheat, which is available throughout the year unlike immature embryos. The wheat genotypes vary in their tissue culture responses with the maximum regeneration potential in GA-2002 (40.92\%).

\section{REFERENCES}

1. Aguado-Santacruz G.A., Velázquez-Ordinola Á., MorenoGómez B., Gómez-Torres L.M., Díaz-Espino L.F. \& Vázquez F.P.G. (2011). Development of long- term and reliable in vitro plant regeneration systems for elite malting barley varieties: optimizing media formulation and explant selection. African Journal of Biotechnology 10(84): 19522 $-19533$.

2. Aydin M., Tosun M. \& Haliloglu K. (2011). Plant regeneration in wheat mature embryo culture. African Journal of Biotechnology 10(70): 15749 - 15755.

DOI: https://doi.org/10.5897/AJB11.1495

3. Barro F., Martin A., Lazzeri P.A. \& Barceló P. (1999). Medium optimization for efficient somatic embryogenesis and plant regeneration from immature inflorescences and immature scutella of elite cultivars of wheat, barley and tritordeum. Euphytica 108(3): 161 - 167. DOI: https://doi.org/10.1023/A:1003676830857

4. Benkirane H., Sabounji K., Chlyah A. \& Chlyah H. (2000). Somatic embryogenesis and plant regeneration from fragments of immature inflorescences and coleoptiles of durum wheat. Plant Cell Tissue and Organ Culture 61: $107-113$.

DOI: https://doi.org/10.1023/A:1006464208686

5. Birsin M.A. \& Ozgen M. (2004). A comparison of callus induction and plant regeneration from different embryo explants of triticale (x Triticosecale wittmack). Cellular and Molecular Biology Letters 9(2): 353 - 361.

6. Chen J.Y., Yue R.Q., Xu H.X. \& Chen X.J. (2006). Study on plant regeneration of wheat mature embryos under endosperm-supported culture. Agricultural Science in China 5(8): $572-578$.

7. Chugh A. \& Khurana P. (2003). Regeneration via somatic embryogenesis from leaf basal segments and genetic transformation of bread and emmer wheat by particle bombardment. Plant Cell Tissue and Organ Culture 74: 151-161.

8. Dudits D., Bogre L. \& Gyogyey J. (1991). Molecular and cellular approaches to the analysis of plant embryo development from somatic cells in vitro. Journal of Cell Science 99: 475 - 484 .

9. Fazeli-Nasab B., Omidi M. \& Tokalldani M.A. (2012). Estimation of callus induction and volume via immature and mature embryo culture and response to in-vitro salt resistance in presence of $\mathrm{NaCl}$ and $\mathrm{ABA}$ in salt tolerant wheat cultivars. International Journal of Agriculture and Crop Science 4(1): 8 - 16 .

10. Gill A.K., Gosal S.S. \& Sah S.K. (2014). Differential cultural responses of wheat (Triticum aestivum 1.) with different explants. Journal of Cell and Tissue Research 
14(2): $4351-4356$.

11. Jia H., Yu J., Yi D., Cheng Y., Xu W., Zhang L. \& Ma Z. (2009). Chromosomal intervals responsible for tissue culture response of wheat immature embryos. Plant Cell Tissue and Organ Culture 97: 159 - 165.

DOI: https://doi.org/10.1007/s11240-009-9510-5

12. Ma H., Gu M. \& Liang G.H. (1987). Plant regeneration from cultured immature embryos of Sorghum bicolor (L.) Moench. Theoretical and Applied Genetics 73: 389 - 394. DOI: https://doi.org/10.1007/BF00262506

13. Mahmood I., Razzaq A., Ashraf M., Hafiz I.A., Kaleem S., Qayyum A. \& Ahmad M. (2012a). In vitro selection of tissue culture induced somaclonal variants of wheat for drought tolerance. Journal of Agricultural Research 50(2): $177-188$.

14. Mahmood I., Razzaq A., Hafiz I.A., Kaleem S., Khan A. A., Qayyum A. \& Ahmad M. (2012b). Interaction of callus selection media and stress duration for in vitro selection of drought tolerant callus of wheat. African Journal of Biotechnology 11(17): 4000 - 4006.

15. Mahmood I., Razzaq A., Khan Z.U.D., Hafiz I.A. \& Kaleem S. (2012c). Evaluation of tissue culture responses of promising wheat (Triticum aestivum L.) cultivars and development of efficient regeneration system. Pakistan Journal of Botany 44(SI): 277 - 284.

16. Murashige T. \& Skoog F. (1962). A revised medium for rapid growth and bio assays with tobacco tissue cultures. Physiologia Plantarum 15: 473 - 497.

DOI: https://doi.org/10.1111/j.1399-3054.1962.tb08052.x

17. Noor S., Ali G.M., Rashid U., Arshad M., Ali S. \& Zafar Y. (2009). Optimization of callus induction and regeneration system for Pakistani wheat cultivars Kohsar and Khyber-87. African Journal of Biotechnology 8(20): 5565 - 5569.

18. Özgen M., Türet M., Altinok S. \& Sancak C. (1998). Efficient callus induction and plant regeneration from mature embryo culture of winter wheat (Triticum aestivum L.) genotypes. Plant Cell Reports 18(3-4): 331 - 335. DOI: https://doi.org/10.1007/s002990050581

19. Razzaq A., Hafiz I.A., Mahmood I. \& Hussain A. (2011). Development of in planta transformation protocol for wheat. African Journal of Biotechnology 10(5): 740 - 750.

20. Sarker R.H. \& Biswas A. (2002). In vitro plantlet regeneration and Agrobacterium mediated genetic transformation of wheat (Triticum aestivum L.). Plant Cell Tissue and Organ Culture 12(2): 155 - 165.

21. Shah M.I., Jabeen M. \& Ilahi I. (2003). In vitro callus induction, its proliferation and regeneration in seed explants of wheat (Triticum aestivum L.) var.LU-26S. Pakistan Journal of Botany 35(2): 209 - 217.

22. Shah M.M., Khalid Q., Khan U.W., Shah S.A.H., Shah S.H., Hassan A. \& Pervez A. (2009). Variation in genotypic responses and biochemical analysis of callus induction in cultivated wheat. Genetics and Molecular Research 8(3): $783-793$.

DOI: https://doi.org/10.4238/vol8-3gmr513

23. Vendruscolo E.C.G., Schuster I., Negra E.S. \& Scapim C.A. (2008). Callus induction and plant regeneration by Brazilian new elite wheat genotypes. Crop Breeding and Applied Biotechnology 8: 195 - 201.

DOI: https://doi.org/10.12702/1984-7033.v08n03a03

24. Wagiran A., Ismail I., Zain C.R.C.M. \& Abdullah R. (2010). Agrobacterium tumefaciens-mediated transformation of the isopentenyltransferase gene in japonica rice suspension cell culture. Australian Journal of Crop Science 4(6): 421 - 429.

25. Yang S., Xu K., Wang Y., Bu B., Huang W., Sun F., Liu S. \& Xi Y. (2015). Analysis of biochemical and physiological changes in wheat tissue culture using different germplasms and explant types. Acta Physiologiae Plantarum 37(6): $120-130$.

DOI: https://doi.org/10.1007/s11738-015-1861-4 